\title{
TENAGA KERJA OUTSOURCING DALAM TINJAUAN EKONOMI ISLAM
}

\author{
Sukamto \\ sukamto@yudharta.ac.id \\ Universitas Yudharta Pasuruan
}

\begin{abstract}
Since the enactment of Law No. 13 of 2003 concerning Employment, outsourcing labor is a reference for employers to add and reduce their employees. Employers feel safe in the context of efficiency in production costs (cost of production) if the outsourced worker is a worker services company, then the person responsible for the outsourced worker is a worker service company. In practice, outsourcing workers often receive unfair treatment in remuneration. In the Islamic economic system justice is upheld and becomes the main foundation in every economic activity. To realize justice, Islam presents the role of the state as a referee who maintains hunting regulations. This includes the obligation of employers to voluntarily return 'surplus value' to their workers. The state must make a forced effort if employers do not want to run it voluntarily. On the other hand, this combination of syirkah-ijarah in the outsourcing labor contract makes workers no longer a separate entity from the means of production as in capitalism. On the contrary, the concept does not make workers the absolute ruler of the means of production.
\end{abstract}

Keywords: Outsourcing, Islamic Economics

\section{PENDAHULUAN}

Tuntunan persaingan dunia usaha yang ketat di era globalisasi saat ini menuntut perusahaan berusaha meningkatkan keninerja usahanya melalui pengelolahan organisasi efektif dan efeisien. Salah satu upaya yang dilakukan adalah dengan mempekerjakan tenaga kerja seminimal mungkin untuk mencapai kontribusi maksimal sesuai sasaran perusahaan. Untuk itu perusahaan berupaya fokus menangani pekerjaan yang menjadi bisnis inti (core-business), sedang pekerjaan penunjang diserahkan pada pihak lain. Proses kegiatan ini dikenal dengan istilah "outsourcing" (OS). Kata outsourcing telah popular di dunia bisnis, kamus besar bahasa Inggris 
terbitan Oxford juga memberikan definisi arti kata dari outsourcing sebagai penyedia jasa atau barang melalui kontrak dari penyedia luar. ${ }^{1}$

OS merupakan tren untuk mengatasi persoalan bisnis yang dihadapi saat ini. Berikut beberapa definisi tentang OS:

1. OS adalah tindakan memindahkan beberapa aktifitas rutin internal perusahaan, termasuk dalam hal pengambilan keputusan kepada pihak lain yang diatur oleh kontrak perjanjian.

2. OS adalah pemindahan tanggung jawab manajemen kepada pihak ketiga secara berkesinambungan di dalam menyediakan layanan yang diatur oleh perjanjian.

3. OS adalah kontrak dengan pihak lain (di luar perusahaan) terhadap fungsi, tugas atau layanan organisasi dalam rangka mengurangi beban proses mempermudah keahlian teknis maupun menghemat biaya.

4. OS adalah aktifitas dimana supplier (pihak pemasok/vendor menyediakan orang dan/atau layanan kepada buyer (pihak perusahaan berdasarkan perjanjian yang telah disepakati.

Dari empat definisi tersebut dapat disimpulkan bahwa OS adalah pendelegasian operasia atau pekerjaan yang bukan inti (non-core) yang semula dilakukan secara internal kepada pihak eksternal yang memiliki spesialisasi untuk malakukan operasi tersebut. Keputusan bisnis OS dilakukan pada umumnya untuk menekan biaya atau meningkatkan fakus pada kompetensi inti. Jadi perusahaan OS adalah perusahaan yang menyediakan jasa tenaga kerja yang meliputi pekerjaan yang akan ditempatkan pada perusahaan yang menginginkannya.

Sejarah outsourcing dimulai tahun 1776 ketika Adam Smith, filosofi ekonomi dunia, melontarkan ide bahwa perusahaan lebih efektif dan efisien apabila salah satu unit bisnisnya diserahkan pengerjaannya kepada perusahaan lain yang memiliki kompetensi dan spesialisasi dalam proses produksi tersebut. Ide Smith ini kemudian dikembangkan oleh Coase pada tahun 1973 yang menyarankan bahwa proses produksi suatu barang

\footnotetext{
${ }^{1}$ Pengertian atau definisi mengenai outsourcing tidak ditemukan dalam Undang-undang No. 13 Tahun 2003 tentang Ketenagakerjaan. Lihat Rr Ani Wijayati, 2004, "Penyerahan Sebagian Pelaksanaan Pekerjaan Kepada Perusahaan Lain (Outsourcing) dalam Undangundang No. 13 Tahun 2003," dalam Bunga Rampai Masalah-masalah Hukum Masa Kini, Jakarta: UKI Press, 66. Sehat Damanik, 2007, Outsourcing dan Perjanjian Kerja Menurut Undang-undang No. 13 Tahun 2003 tentang Ketenagakerjaan, (Jakarta: DSS Publishing), cet. 2,95 .
} 
seharusnya hanya diorganisir oleh perusahaan apabila ongkos produksinya lebih rendah daripada harga dipasaran.

Tahun 1980 outsourcing dipakai pertamakali untuk customer service dan pelayanan call center. Pada era tahun 1990-an, tren penggunaan outsourcing ini telah dilakukan di hampir semua perusahaan di dunia, sehingga masa itu popular disebut 'Masa Dentuman Besar Outsourcing'. Era tahun 1990-an, Australia bahkan mulai menggunakan tenaga outsourcing untuk pegawai negeri sipilnya. Data menarik dipublikasikan oleh Mercer dan Cranfiled School of Management bahwa lebih dari 90 persen perusahaan di Eropa dan Amerika Utara menggunakan outsourcing untuk salah satu bagian bisnisnya. $^{2}$

\section{TUJUAN DAN MANFAAT OUTSOURCING}

Terdapat banyak keuntungan penggunaan outsourcing. Tujuan utama bagi perusahaan menggunakan sistem outsourcing didasarkan pada pertimbangan faktor ekonomi untuk meningkatkan keuntungan. Pada tahun 1955 sampai dengan tahun 1990 tujuan penggunaan outsourcing adalah untuk mendapatkan tenaga kerja murah melalui upah rendah. Setelah tahun 2000, penggunaan outsourcing bertujuan mendukung transformasi perusahaan. Disini berarti perusahaan dapat konsentrasi pada bisnis utamanya. Perusahaan perlu konsentrasi pada bisnis utamanya karena kompetisi persaingan yang semakin ketat untuk menjaga keutuhan perusahaan.

Manfaat lain dari outsourcing adalah perusahaan dapat memberikan pelayanan terbaik kepada pekerjanya. Dalam artian, karena struktur organisasi perusahaan semakin ramping dan menyusutnya jumlah pekerja dilingkungan perusahaan, maka perusahaan dapat meningkatkan kesejahteraan pekerjanya. Manfaat terakhir dari outsourcing adalah penciptaan lapangan tenaga kerja baru dan agen-agen penyedia tenaga kerja. Negara China menjadi Negara industri seperti saat ini karena didukung oleh sistem outsourcing yang sangat kuat.

Dengan penyerahan pengelolaan tenaga kerja ke perusahaan outsourcing, maka perusahaan tidak perlu lagi mengurusi perekrutan, pelatihan, administrasi tenaga kerja dan penggajian dan lain - lainnya

\footnotetext{
${ }^{2}$ Ponomariov, B \& Kingsley G, 2008, 'Applicability of the normative model of outsourcing in the public sector: the case of a state transportation agency', Public Organization Review, 8:253-27
} 
disetiap bulannya. Keuntungan lainnya adalah, Perusahaan tidak lagi direpotkan dengan urusan pesangon, THR, PHK dan masalah lainnya. Karena hal ini telah dikelola oleh perusahaan outsourcing.

Adapun kerugian dari penggunaan outsourcing adalah sebagai hidden cost, yang timbul akibat outsourcing yang dapat merugikan pengusaha, pekerja, serikat pekerja/serikat buruh (SP/SB). Bagi pengusaha, jika dilihat dalam perspektif teori Human Resource Management, maka dimasa depan perusahaan harus membayar mahal dari praktek penggunaan outsourcing. Kerugiaan tersebut antara lain :

1. Outsourcing dapat menurunkan kemampuan manajemen dalam hal manajerial perusahaan. Sementara bagi para pekerja di perusahaan tersebut juga menurunkan tingkat keahlian pekerjanya, karena tingginya tingkat pergantian karyawan.

2. Dapat menurunkan kualitas suatu hasil produksi karena dikerjakan oleh supplier dan perusahaan kesulitan untuk melakukan kontrol.

3. Menimbulkan perselisihan hubungan industrial pada perusahaan apabila supplier gagal memenuhi ketentuan peraturan hukum ketenagakerjaan yang berlaku.

Sementara bagi pekerja dan organisasi buruh, kerugian dari outsourcing adalah:

1. Tidak ada jaminan dimasa depan, karena praktek outsourcing yang digunakan dalam strategi pengelolaan karyawan adalah menggunakan tenaga kerja dengan sistem berbasis kontrak kerja. Di Australia misalnya, sejak tahun 1990 ada peningkatan jumlah karyawan kontrak karena penggunaan outsourcing. Bagi perusahaan keuntungan utama dari kontrak adalah penurunan ongkos kerja. Saat ini jumlah pekerja kontrak meningkat diberbagai belahan dunia menurut riset MCDonal. Pekerja kontrak beresiko untuk tidak mendapatkan pengembangan karir dan kepastian hubungan kerja dimasa depan. Pekerjaan dengan kontrak pendek beresiko menghapuskan sistem jenjang karir pekerja pada perusahaan. ${ }^{3}$

2. Adanya diskriminasi sistem pengupahan dan kesejahteraan antara pekerja outsourcing dan bukan outsourcing. Pekerja outsourcing beresiko tidak

\footnotetext{
${ }^{3}$ Mukherji S \& Ramachandran, 2007, Outsourcing; practice in search of a Theory, IIMB Management Review. Vol 132.
} 
mendapatkan struktur dan skala upah yang naik secara berkala dan berjenjang karena kontrak jangka pendek.

3. Menurunkan jumlah keanggotaan serikat pekerja dimasa depan. Dari data yang ada, tahun 1990, saat outsourcing menjadi popular maka pada saat yang sama terjadi penurunan jumlah anggota serikat pekerja pada Negara maju yang mengunakan sistem outsourcing. Antara tahun 2000 sampai tahun 2007 jumlah anggota serikat pekerja di Australia turun dari 2,508,800 anggota menjadi 1,833,700 anggota. Sedangkan, dari tahun 2008 sampai 2012 terjadi penurunan dari 43\% menjadi 18\% untuk pekerja pria, dan dari $35 \%$ ke $18 \%$ untuk pekerja perempuan. Bukan hanya Australia, namun juga di Eropa dan separuh dari Negara AngloAmerika sejak era tahun 1990-an. ${ }^{4}$

Bagi Negara, sistem outsourcing juga menjadi penyebab bagi tingginya tingkat perselisihan hubungan industrial. Perselisihan hubungan industrial dapat timbul karena perbedaan kesejahteraan antara pekerja outsourcing dan bukan outsourcing meskipun dalam satu perusahaan dengan tingkat pekerjaan dan tugas yang sama.

\section{REALITA TENAGA KERJA OUTSOURCING PASCA UU NO. 13 TAHUN 2003}

Dalam UU No.13 tahun 2003 secara eksplisit tidak disebutkan istilah outsourcing, tetapi praktek outsourcing dimaksud dalam undang - undang ini dikenal dalam dua ( 2 ) bentuk, yaitu "pemborongan pekerjaan dan penyediaan jasa pekerja / buruh". 5 Sejak diberlakukannnya undang-undang tersebut ketenagakerjaan, outsourcing menjadi menjamur. Hal ini disebabkan perusahaan dalam rangka efesiensi biaya produksi (cost of productiaon) merasa aman jika buruh yang dioutsourcing adalah buruhnya perusahaan jasa pekerja. Sehingga yang bertanggung jawab terhadap buruh outsourcing adalah perusahaan jasa pekerja. Perusahaan-perusahaan ini merasa diback up oleh pasal 66 ayat 2 yang menyatakan bahwa atura $\mathrm{n}$ perusahaan jasa pekerja ada hubungan kerja dengan buruh yg diempatkan

\footnotetext{
${ }^{4}$ Benson, J \&Ieronime, N 1996, Outsourcing decisions; Evidence From Australia Based Enterprises, International Labour Review. Vol 135, no. 1

${ }^{5}$ Abdul Hakim, 2007, Hukum Ketenagakerjaan Indonesia Berdasarkan Undang-undang No. 13 Tahun 2003, (Bandung, Adya Bhakti), 151.
} 
pada perusahaan pengguna. ${ }^{6}$ Di lain pihak, pihak buruh yang dioutsourcing juga merasa diback up oleh pasal I butir 15 yang menyatakan bahwa hubungan kerjanya bukan dengan perusahaan jasa pekerja melainkan dengan perusahaan pengguna. Hal ini disebabkan unsur adanya upah, pekerjaan, dan perintah hanya ada dalam hubungannya dengan perusahaan pengguna bukan dengan perusahaan jasa pekerja. Kedua, pasal itu juga menimbulkan ketidakpastian hukum bagi pengusaha dan buruh apalagi outsourcing pekerja pada saat ini sedang hangat diperbincangkan. Banyak perusahaan memutuskan hubungan kerja dengan buruh untuk selanjutnya direkrut kembali melalui perusahaan jasa pekerja (outsourcing pekerja). Hal ini berarti bahwa melalui pasal 66 ayat (2)a Undang-undang No. 13 tahun 2003 Tentang Ketenagakerjaan Pemerintah melegalkan bukan sekededar perbudakan modern melainkan juga termasuk human-trafficking. ${ }^{7}$

Hakekat dari semua aturan tersebut adalah bahwa perusahaan dapat memberikan pelaksanaan pekerjaan kepada perusahaan lain, selama pekerjaan itu bukan merupakan jenis pekerjaan utama perusahaan atau bukan merupakan bisnis inti perusahaan. Perusahaan juga diwajibkan untuk membuat alur produksi untuk membuktikan bahwa itu bukan bisnis inti perusahaan. Ketentuan lainnya adalah bahwa perusahaan penyedia tenaga kerja harus berbadan hukum dan apabila tidak maka status beralih menjadi hubungan kerja pekerja/buruh dengan perusahaan pemberi pekerjaan. Perlindungan upah dan kesejahteraan, syarat-syarat kerja, serta perselisihan yang timbul menjadi tanggungjawab perusahaan penyedia jasa pekerja/buruh. ${ }^{8}$

Ada beberapa kelemahan mendasar dalam sistem outsourcing di Indonesia. Pertama, secara perspektif teori, penyerahan pekerjaan kepada perusahaan lain seharusnya ditujukan kepada perusahaan yang berada diluar

\footnotetext{
${ }^{6}$ Mengenai Pasal 65 Ayat (8) Undang-undang No. 13 Tahun 2003 tentang Ketenagakerjaan yang mengatur dalam hal pekerja outsourcing tidak mendapatkan hak-haknya dalam hubungan kerja dengan perusahaan penyedia jasa beralih hubungan kerjanya kepada perusahaan pengguna jasa. Djimanto dari APINDO menyebutkan bahwa hal ini sangat merugikan dan memberatkan pengusaha oleh karena maksud semula dari perusahaan mempekerjakan pekerja outsourcing memang demi alasan efisiensi, dikutip dari pendapat Djimanto dalam acara Workshop Penyusunan Rancang Bangun Hubungan Industrial, diselenggarakan oleh Direktorat Jenderal Pembinaan Hubungan Industrial dan Jaminan Tenaga Kerja, Hotel Kartika Chandra Jakarta, 14 Juli 2009

7 Andari Yurikosari, 2010, Pemutusan Hubungan Kerja di Indonesia, (Jakarta: Fakultas Hukum Universitas Indonesia), 83-84.

${ }^{8}$ Andari Yurikosari,........ 360-361
} 
wilayah perusahaan tersebut atau memiliki spesialisasi khusus, sehingga bisa memproduksi lebih murah. Misalnya sebuah perusahaan mobil dari Jerman, perusahaan ini menyerahkan pekerjaan pembuatan spare part nya kepada perusahaan di Indonesia, karena ongkos tenaga kerja di Indonesia jauh lebih murah daripada di negara asalnya. Selain itu, adanya alasan bahwa perusahaan di Indonesia tersebut terkenal dengan spesialisasi pembuatan spare part berkualitas baik. Namun pada prakteknya di Indonesia, penyerahan pekerjaan kepada perusahaan lain dilakukan kepada perusahaan yang sewilayah atau bahkan sama standar upah minimumnya. Sehingga, seharusnya dipahami perusahaan tidak dapat mencari pekerja dengan upah yang lebih rendah karena standar skala upahnya sama.

Kelemahan kedua, penentuan dan pembuat alur kegiatan bahwa pekerjaan itu bukan pekerjaan utama, sebagaimana yang diamanatkan oleh undang-undang, pada kenyataannya dilakukan perusahaan pemberi kerja itu sendiri. Seharusnya justifikasi tersebut dilakukan oleh sebuah lembaga independen untuk dapat memetakan alur kegiatan secara lebih objektif.

Kelemahan ketiga, outsourcing dalam penerapannya seharusnya tidak mengurangi hak-hak pekerja. Hal ini sesuai dengan ketentuan dari Mahkamah Konstitusi Nomor 27/PUU-IX/2011 tanggal 17 Januari 2012 yang ditindaklanjuti dengan surat edaran Dirjen PHI dan Jamsos Kemenakertrans NO. B31/PHIJSK/2012 tentang Pelaksanaan Putusan Mahkamah Konstitusi Nomer 27/PUU-IX/2011. Intinya, apabila dalam perjanjian kerja antara perusahaan penerima pemborongan pekerjaan/penyedia jasa kerja dengan pekerja/buruhnya tidak memuat syarat adanya pengalihan perlindungan hakhak bagi pekerja/buruh yang objek kerjanya tetap ada (sama) kepada perusahaan penerima pemborongan atau penyedia jasa lainnya, maka hubungannya adalah PKWTT (Perjanjian Kerja Waktu Tidak Tertentu) atau tetap. Jika sudah memuat persyaratan pengalihan perlindungan hak-hak pekerja buruh ke perusahaan penerima pemborongan atau penyedia jasa lainnya, maka diperbolehkan menjadi PKWT (Perjanjian Kerja Waktu Tertentu) atau sementara.

Selain itu, kelemahan lain adalah pelaksanaan persetujuan perjanjian kerja antara perusahaan penyedia jasa dan pemberi pekerjaan, seringkali tidak mengikutsertakan perwakilan pekerja. Sehingga sering kali pula pekerja tidak mengetahui posisinya dengan jelas, dalam hal perlindungan upah, hak-hak pekerja dan syarat-syarat kerja serta apabila terdapat perselisihan hubungan industrial. 
Di Indonesia, perjuangan yang dilakukan oleh para buruh utamanya tenaga outsourcing untuk memperoleh hak-haknya sudah dilakukan dalam jangka waktu cukup lama. Karena Indonesia tercatat sebagai negara Asia pertama yang merayakan tanggal 1 Mei sebagai hari buruh, perjuangan para buruh di Indonesia untuk menuntut haknya membuahkan hasil melalui pengesahan UU Kerja No. 12 Tahun 1948, pada pasal 15 ayat 2, dinyatakan bahwa "Pada hari 1 Mei buruh dibebaskan dari kewajiban kerja.". Tapi peringatan hari buruh di Indonesia juga sempat mengalami fluktuatif pergerakan ketika zaman orde baru, karena semasa orba aksi untuk peringatan May Day masuk kategori aktivitas pemberontakan yang bertujuan untuk "menggulingkan" pemerintahan dan juga diidentikkan dengan ideologi komunis. Akan tetapi setelah era orde baru berakhir, walaupun bukan hari libur, setiap tanggal 1 Mei kembali marak dirayakan oleh buruh di Indonesia dengan demonstrasi di berbagai kota. Permasalahan yang terjadi tentang pemberian honor dan permasalahan sistemik yang menimpa para buruh terus terjadi tiap tahunnya, bahkan cenderung bertambah permasalahannya. Di tahun ini para buruh di Indonesia setidaknya mengajukan 9 tuntutan kepada pemerintah RI, yaitu:

1. Penghapusan sistem outsourcing (tenaga alih daya),

2. Revisi Kebutuhan Hidup Layak (KHL) menjadi 80 poin,

3. Penolakan penangguhan kenaikan Upah Minimum Regional (UMR),

4. Penolakan kenaikan harga bahan bakar minyak (BBM),

5. Penghentian pemberangusan serikat pekerja,

6. Penolakan potongan gaji untuk iuran Badan Penyelenggara Jaminan Sosial (BPJS),

7. Pengadaan rumah layak huni untuk buruh,

8. Pengadaan beasiswa untuk buruh,

9. Penetapan 1 Mei menjadi hari libur nasional.

Dari kesembilan tuntutan yang diajukan setidaknya terdapat gambaran adanya ketidakadilan dari sistem honor yang diberikan kepada para buruh saat ini. Padahal seharusnya para pimpinan dan pemilik perusahaan memiliki kewajiban terhadap kaum buruh untuk memperlakukannya dengan baik dan tidak membuat "jurang pemisah" antara dirinya dan para buruh. Oleh karena itu, untuk memberikan solusi dari tiap permasalahan sistem honor yang layak diterima para buruh sebagai hak yang harus diterimanya. Pembahasan ini mengkaji pandang Islam terhadap mekanisme tenaga kerja outsourcing, pemenuhan hak dan kewajibannya sebagai buruh/pekerja. 


\section{TINJAUAN EKONOMI ISLAM TENTANG TENAGA KERJA OUTSOURSING}

Pada prinsipnya, pembahasan terkait dengan pemanfatan tenaga kerja orang lain atau atas nama lembaga dalam sistem ekonomi Islam masuk dalam kajian ijarah. ${ }^{9}$ Para empat mazdhab, Hanafiah, Syafi'iyah, Malikiyah dan Hanafiyah mendifinisikan konsep ijarah dengan menjadikan milik sesuatu kemanfaatan dalam waktu tertentu dengan pengganti. ${ }^{10}$ Bahkan Ibn Rusd berpendapat bahwa kemanfaatan, walaupun tidak berbentuk, dapat dijadikan alat pembayaran menurut kebiasaan. ${ }^{11}$ Hal ini menunjukkan bahwa dalam kontrak ijarah senantiasa berdasarkan adanya kemanfaatan berupa upah antara pekerja dengan pemilik perusahaan setelah kepemilikan barang berlangsung.

Realitas kontrak kerja yang berujung pada pemberlakuan sistem upah mengupah dalam ekonomi Islam dapat dijumpai berdasarkan Al-Qur'an dan As-Sunah.

a. Al-Qur'an

'Jika mereka menyusukan (anak-anakmu) untukmu, maka berikanlah mereka upahnya." (QS. Thalaq: 6)

"Salah seorang dari kedua wanita itu berkata," Ya ayahku, ambillah ia sebagai orang yang bekerja (pada kita), karena sesungguhnya orang yang paling baik kamu ambil untuk bekerja (pada kita) ialah orang yang kuat lagi dapat dipercaya." Berkatalah dia (Syu'aib), "Sesungguhnya aku bermaksud menikahkan kamu dengan salah seorang kedua anakku ini,atas dasar bahwa kamu bean jika cukupkan sepuluh tahun, maka itu adalah (suatu kebaikan) dari kamu." (QS. Al-Qashash: 26-27)

b. As-Sunah

"Berikanlah upah pekerja sebelum keringatnya kering." (HR. Ibn Majah dari Ibn Umar)

"Barang siapa yang meminta untuk menjadi buruh, beritahukanlah ${ }_{12}$ upahnya." (HR. Abd Razaq dari Abu Hurairah)

\footnotetext{
${ }^{9}$ Secara etimologi Ijarah adalah Bay' al-manfaat (menjual manfaat) secara termininologi berarti akad kemanfaatan dengan penganti. Ada juga yang mendefinisikan dengan akad jual beli jasa dan akad sewa-menyewa. Dalam Alaudin Al-Kasani, 2008, Badai' As-Shanai' fi tartib Asy-Syara'i, (Kairo: Dar Shaqafah), 231.

${ }^{10}$ Muhammad Asy-Syarbini,1996, Mugni Muhtaj, (Beirut: Dar Fikr), 398

${ }^{11}$ IbnRusyd, 1995, Bidayah Al-Mujtahid wa Nihayah Al-Muqtashid, Juz II,(Beirut: Dar Fikr), 218.
} 
Pengakuan kedua ayat Al-Qur'an terhadap tenaga kerja di atas menjelaskan bahwa mengambil tenaga keja orang lain untuk diambil kemanfaatnya yang berakhir dengan memberikan imbalan/upah sudah menjadi realitas sosial. Point terpenting dalam hal ini adalah saling memperoleh manfaat. Pemilik kerja memperoleh barang dan jasa yang menjadi keinginannya sedang pekerja memperoleh upah sesuai dengan kesepakatan awal.

Perjanjian dalam sistem tenaga kerja outsourcing sebagimana tertuang dalam UU No.13 tahun 2003 dapat diartikan sebagai penyerahan sebagian pelaksanaan pekerjaan pada perusahaan lainnya melalui perjanjian pemborongan pekerjaan atau dengan penyediaan jasa pekerja/buruh. Perjanjian dalam outsourcing ada dua, yaitu perjanjian antara perusahaan pemberi pekerjaan dengan perusahaan penyedia jasa pekerja/buruh dan perjanjian antara perusahaan penyedia jasa pekerja/buruh dengan karyawan. Kedua, mekanisme outosurcing dalam sistem ekonomi Islam diartikan dengan akad syirkah abdan dan ijarah. Dimana dalam syirkah abdan perusahaan pemberi pekerjaan memberi kontribusi lapangan pekerjaan dan perusahaan penyedia jasa pekerja/buruh memberi kontribusi tenaga kerja. ${ }^{13}$ Sedangkan dalam ijarah penyedia jasa pekerja/buruh disebut sebagai orang yang mengontrak (musta'jir) dan karyawan sebagai orang yang dikontrak tenaganya (ajir). ${ }^{14}$

Dalam masalah upah mengupah pada transaksi jasa seperti outsourcing sebagaimana berlaku akad ijarah adalah lebih menekankan hubungan kemintraan (partnership) antara pemilik jasa ((pekerja, karyawan, buruh dll) dan pengguna jasa (majikan perusahaan). Prinsip kemitraan ini didasarkan kepada asumsi bahwa masing-masing memiliki sesuatu yang tidak dimiliki oleh pihak lain di mana mereka saling membutuhkan satu sama lain. Sehingga dalam hal ini tidak ada paradigma kelas atas yang seolah dibutuhkan dan kelas bawah karena mereka lebih membutuhkan.

Dengan prinsip ini, paradigma yang dibangun adalah prinsip persamaan dan keadilan, artinya masing-masing memiliki hak dan kewajiban yang sama untuk menjalankan amanahnya. Misalnya, hak seorang pekerja adalah mendapatkan upah yang layak dan mengetahui kadar upah sebelum ia

\footnotetext{
${ }^{13}$ Kamil Musa, 1995, Ahkamul Muamalah, (Beirut: Muasasah Risalah), 165.

${ }^{14}$ Kreteria akad ijarah adalah memenuhi rukun dan syaratnya. Rukun ijarah; aqid (orang yang akad), shighat akad, ujrah (upah), manfaat. Syarat sah: adanya keridhaan dari kedua pihak yang berakat, barang jelas bermanfaat. Dalam Kamil Musa, 176.
} 
melakukan sebuah pekerjaan, ia juga berkewajiban bekerja sebaik-baiknya sebagai amanah dari pihak pengguna jasa. Sebaliknya pihak pengguna jasa berhak untuk mendapatkan manfaat jasa sebagaimana yang disebutkan dalam akad, dan berkewajiban memberitahukan kadar upah yang akan diberikan (transparan).

Transparansi terkait kadar upah ini penting untuk menghindari adanya gharar (ketidakjelasan) dalam transaksi, yang dilarang dalam sistem ekonomi Islam. Ketidaktransparanan dalam upah juga bisa menimbulkan terjadinya eksploitasi terhadap pihak yang lemah, yang biasanya dialami oleh pihak pekerja atau buruh. Oleh karean itu, sangat logis jika kemudian Rasulullah saw memerintahkan para pengguna jasa (musta'jir) untuk senantiasa memberikan transparansi terhadap upah yang akan diterima oleh pemilik jasa (ajir).

Sesuai dengan konsep ijarah, upah pekerja ditentukan berdasarkan manfaat tenaga, sejauhmana tenaga seseorang memberikan kontribusi manfaat bagi pengguna jasa (musta'jir), dan bukan berdasarkan tenaga itu sendiri. Manfaat tenaga dalam perjanjian outsourcing adalah seperti komoditas yang memiliki bursa (pasar), yang di dalamnya berlangsung mekanisme penawaran dan permintaan (suplay and demand). Harga seorang tenaga kerja dalam outsourcing juga ditentukan berdasarkan harga di pasar, dan oleh karenanya tidak boleh menetapkan harga manfaat secara paksa sebagaimana tidak diperkenankan harga komoditas. Oleh karena itu, harus membiarkan penentuan harga manfaat tenaga kerja, yakni upah seorang pekerja (ajir) menurut apa yang ditentukan oleh pasar terhadap manfaat (jasa) para pekerja.

Kalau dalam transaksi jual beli berlangsung secara taradli (sukarela) di antara dua belah pihak, begitu juga halnya yang terjadi dalam transaksi jasa. Jika keduanya telah sepakat atas suatu upah, sedang upah tersebut telah disebutkan (al-ajr al-musamma), maka keduanya terikat dengan upah tersebut. Dan jika keduanya tidak sepakat atas suatu upah, maka keduanya terikat dengan apa yang dikatakan oleh di pasar umum terhadap manfaat tenaga tersebut (al-ajr al-mitsl). ${ }^{15}$ Hanya saja, dalam upah dalam perjanjian outsourcing tidak bersifat abadi, namun terikat dengan masa tertentu yang

\footnotetext{
${ }^{15}$ Dalam hal ini Imam Syafi'i membagi upah menjadi dua; upah musamma yaitu upah yang diberikan kepada buruh dengan kesepakatan kedua belah pihak. Upah misli adalah upah yang diberikan kepada buruh dengan upah umumnya. Lihat dalam Abu Ishaq Asy-Syirazi, 1997, Al-Muhazdab, (Mesir: Al-Babi Al-Halabi), 231.
} 
telah disepakati oleh keduanya. Jika masanya telah berakhir, atau pekerjaan telah selesai, maka bisa dimulai lagi ketentuan baru terhadap upah sesuai dengan penilaian pasar umum terhadap manfaat tenaga saat melakukan penentuan upah.

Memang, perintah Rasulullah saw. untuk menyegerakan pemberian upah tidak mutlak mengandung makna kewajiban, karena masalah pembayaran gaji atau upah bisa juga ditentukan berdasarkan syarat, kesepakatan atau 'urf (kebiasaan yang berlaku), sebagaimana pembayaran harga dalam jual beli barang. Namun apapun keadaannya, perintah tersebut tetap mengandung anjuran untuk membayarkan upah kepada pekerja sesegera mungkin, apabila pengguna jasa (musta'jir) telah memiliki kelapangan harta. Karena setiap penundaan pembayaran bagi seorang yang telah mampu berarti kedhaliman terhadap hak orang lain, sebagaimana yang diterangkan dalam ungkapan hadist diatas. Dengan prinsip kemitraan (partnership) tersebut, dalam sistem ekonomi Islam kedudukan seorang pekerja (ajir) dan pengguna jasa (musta'jir) dalam posisi yang sejajar dan menutup rapat-rapat bagi terjadinya eksploitasi terhadap pihak yang lemah. Sebaliknya, Islam selalu berusaha menciptakan hubungan yang harmonis antara keduanya. Dalam sebuah hadist Rasulullah bersabda: "Mereka (para tenaga kerja) itu adalah saudara kalian yang dijadikan oleh Allah swt. Di bawah kekuasaanmu, dan barang siapa dijadikan Allah swt untuk menguasai saudaranya, maka hendaklah ia beri makan dari apa yang ia makan dan ia beri pakian dari apa yang ia pakai, tidak membebani dengan sebuah pekerjaan di luar kemampuannya, dan apabila membebani pekerjaan yang di luar kemampuannya maka hendaklah ia membantunya."

Yang lebih menarik, dalam ungkapan hadist tersebut adalah bahwa Rasulullah saw menyampaikan pesan dalam konteks seorang pekerja (buruh, pelayan, pegawai, karyawan dll) untuk lebih layak mendapatkan perlakuan baik. Bahkan Rasululah saw juga menganjurkan untuk senantiasa memberikan hak-hak secara lebih banyak kepada seorang pegawai.

Dalam riwayat lain sebagaimana yang diriwayatkan dalam suatu hadist oleh Bukhari dan Muslim, Amsyu bin Maqruri Bin Suwaid, berkata : "kami melewati Abu Dzar di Rabadzah dan ia mengenakan Burdun (baju rangkap) begitu juga budaknya. Abu Dzar ra berkata :" Pernah terjadi katakata kasar antara saya dan saudara saya yang Ibunya bukan bangsa Arab (Sahaya), saya hinakan ia dari segi Ibunya. Lalu dia mengadu kepada Rasulullah SAW. Maka setelah saya berjumpa Rasulullah SAW, Beliau 
berkata : "Kamu ini orang yang memiliki sifat Jahiliyah, hai Abu Dzarr ". Kata saya: Barang siapa yang memaki-maki orang tentu bapak dan ibunya akan dimaki-maki pula. Berkata Beliau : "Sesungguhnya kamu ini orang yang memiliki sifat jahiliyah, sahaya-sahaya itu adalah saudara kamu pula yang kebetulan di bawah tangan kamu. Maka berilah makan seperti kamu makan, berilah pakaian seperti kamu pakai, dan janganlah mereka dipaksa bekerja lebih dari tenaga mereka, jika akan dipaksakan juga mereka harus kamu bantu"

Hadist tersebut menjelaskan bahwa memperlakukan para pekerja/buruh sudah seharusnya sama seperti memperlakukan diri kita sendiri. Selain itu terdapat juga ajakan untuk lemah lembut dan tidak merasa mempunyai strata sosial dibandingkan para buruh. Dengan demikian gap antara pimpinan atau pemilik perusahaan dengan buruh dapat dihindari.

Selanjutnya apabila sudah terjadi keharmonisan antara buruh dan pimpinannya, dibutuhkan juga peran serta pemerintah untuk membuat regulasi yang mengatur sistem honor di setiap perusahaan yang ada dalam suatu negara. Setidaknya ada empat jenis tindakan yang dapat dilakukan pemerintah dalam mengatur kehidupan perekonomian industri yang berkaitan dengan para buruh dan pimpinannya, yaitu:

1. Membuat regulasi dan memastikan kesesuaiannya dengan penerapan di industri melalui edukasi dan sosialisasi, disertai dengan pemberian hukuman apabila ada yang melanggar regulasi yang telah ditetapkan.

2. Pemeliharaan kondisi investasi yang aman dan sehat serta berfungsi dengan baik.

3. Memodifikasi alokasi sumber daya dan pendistribusian pendapatan secara adil dan merata.

4. Mengambil langkah-langkah strategis dalam bidang produksi dan pembentukan modal guna mempercepat pertumbuhan ekonomi.

Dengan demikian konsep mensejahteraan buruh dalam pandangan Islam bertujuan guna memenuhi kebutuhan dasar (makanan, pakaian, dan perumahan) dari setiap individu tanpa adanya pembedaan untuk mendapatkan sumber daya yang tersedia. Karena pemenuhan kebutuhan dasar membuat para buruh akan mampu untuk melakukan kegiatan produksi secara maksimal dan bekerja dengan optimal. Dengan demikian para pemilik perusahaan juga dapat meraih keuntungan lebih di perusahaannya, dan juga pemerintah akan merasakan kebermanfaatannya dengan kemajuan perekonomian dalam suatu negara. Sehingga benarlah pendapat Umar Chapra salah seorang penasehat 
pada Islamic Development Bank (IDB), ${ }^{16}$ bahwa tujuan Syariah Islam untuk merealisasikan kesejahteraan manusia tidak hanya terdapat pada kesejahteraan secara ekonomi, tetapi juga persaudaraan dan keadilan sosioekonomi, kedamaian dan kebahagiaan jiwa, serta keharmonisan keluarga sosial.

\section{KESIMPULAAN}

Berdasarkan pembahasan tentang tenaga kerja outsourcing dalam tinjauan ekonomi Islam dapat disimpulkan:

1. Mekanisme tenaga kerja outosurcing dalam sistem ekonomi Islam diartikan dengan akad syirkah abdan dan ijarah. Dimana dalam syirkah abdan perusahaan pemberi pekerjaan memberi kontribusi lapangan pekerjaan dan perusahaan penyedia jasa pekerja/buruh memberi kontribusi tenaga kerja. Sedangkan dalam ijarah penyedia jasa pekerja/buruh disebut sebagai orang yang mengontrak (musta'jir) dan karyawan sebagai orang yang dikontrak tenaganya (ajir). Hal ini akan menjadikan buruh tak lagi menjadi entitas terpisah dengan alat produksi seperti dalam kapitalisme. Sebaliknya, konsep itu pun tak menjadikan buruh sebagai penguasa mutlak atas alat produksi.

2. Pada prinsipnya, hubungan kemintraan antara pekerja dan pengguna jasa yang diharapkan dalam ekonomi Islam adalah hubungan yang dibangun berdasarkan nilai-nilai amanah yang harus ditunaikan masing-masing pihak, ketika seseorang telah menunaikan amanahnya dengan baik, maka ia adalah seorang mitra yang baik dan wajib diberikan hak-haknya dengan baik pula.

\section{DAFTAR PUSTAKA}

Al-Kasani, Alaudin, 2008, Badai' As-Shanai' fi tartib Asy-Syara'i, Kairo: Dar Shaqafah, Kairo.

Asy-Syarbini, Muhammad, (1996), Mugni Muhtaj, Beirut: Dar Fikr.

Asy-Syirazi, Abu Ishaq,1997, Al-Muhazdab, Mesir: Al-Babi Al-Halab.

Benson, J \&Ieronime, N 1996, Outsourcing decisions; Evidence From Australia Based Enterprises, International Labour Review.

\footnotetext{
${ }^{16}$ Umar Chapra, 1999, Islamic And The Economic Challence, (The Islamic Foundation and the International Institute of Islamic Thought, Herndon USA), 234-237.
} 
Chapra, Umar, Islamic And The Economic Challence, The Islamic Foundation and the International Institute of Islamic Thought, Herndon USA.

Damanik, Sehat, 2007, Outsourcing dan Perjanjian Kerja Menurut Undangundang No. 13 Tahun 2003 tentang Ketenagakerjaan, Jakarta: DSS Publishing.

Hakim, Abdul, 2007, Hukum Ketenagakerjaan Indonesia Berdasarkan Undang-undang No. 13 Tahun 2003, Bandung: Adya Bhakti.

IbnRusyd, 1995, Bidayah Al-Mujtahid wa Nihayah Al-Muqtashid, Juz II, Beirut: Dar Fikr.

Mukherji S \& Ramachandran, 2007, Outsourcing; practice in search of a Theory, IIMB Management Review.

Musa,Kamil, 1995, Ahkamul Muamalah, Beirut: Muasasah Risalah.

Ponomariov, B \& Kingsley G, 2008, 'Applicability of the normative model of outsourcing in the public sector: the case of a state transportation agency', Public Organization Review.

Wijayati, Rr Ani, 2004, "Penyerahan Sebagian Pelaksanaan Pekerjaan Kepada Perusahaan Lain (Outsourcing) dalam Undang-undang No. 13 Tahun 2003," dalam Bunga Rampai Masalah-masalah Hukum Masa Kini, Jakarta: UKI Press.

Yurikosari, Andari, 2010, Pemutusan Hubungan Kerja di Indonesia, Jakarta: Fakultas Hukum Universitas Indonesia. 
$80\}\{$ Tenaga Kerja Outsourcing dalam Tinjauan Ekonomi Islam

..::: Malia: Jurnal Ekonomi Islam, Volume 11 Nomor 1 Desember 2019 :::.. 